МЕДІАТВОРЧІСТЬ ЯК ЗАСІБ РОЗВИТКУ МЕДІАКУЛЬТУРИ ПЕДАГОГІВ У ЗАКЛАДАХ ПІСЛЯДИПЛОМНОЇ ПЕДАГОГІЧНОЇ ОСВІТИ

\title{
MEDIACREATIVITY AS A MEANS OF DEVELOPMENT OF MEDIACULTURE OF TEACHERS IN POSTGRADUATE PEDAGOGICAL EDUCATION INSTITUTIONS
}

\begin{abstract}
У статті висвітлено проблему розвитку медіакультури сучасного педагога засобами медіатворчості в закладі післядипломної педагогічної освіти. Актуальність матеріалу обумовлена зміною вимог до профресійної діяльності вчителів в умовах інформаційного суспільства. Розкрито сутність понять медіакультура й медіатворчість учителя, які характеризуються рівнем сфрормованості навичок творчого сприйняття, аналізу, інтерпретації, створення власних медіаресурсів та вміннями застосовувати ці навички у професійній діяльності. Акцентовано увагу на пріоритетному завданні для кожного педагога - навчитися створювати власні медіапродукти, оцінювати якість інфрормації, проявляти вибірковість у процесі їі споживання, критично ставитися до джерел інорормаціі.

Представлено різноманітні підходи до розвитку медіакультури педагогів у системі післядипломної освіти: через упровадження спеціального курсу з медіакультури, через інтеграцію медіаосвітніх технологій в освітній процес, шляхом виконання індивідуальних творчих завдань за допомогою медіаресурсів. Приділено увагу правилам культури спілкування в інфрормаційному просторі, способам захисту від негативних впливів медіа у процесі комунікаціі.

Обгрунтовано методичні умови ефективного розвитку медіакультури педагогів у закладі післядипломної педагогічної освіти: формування у педагогів позитивної мотивації до використання медіаресурсів; наявність у вчителів знань та умінь щодо використання інформаційно-цифррових технологій; використання інтерактивних комунікацій у прочесі навчання; залучення слухачів до активної творчої медійної діяльності шляхом створення власних освітніх продуктів. З'ясовано, що розвиток медіакультури та медіатворчості педагогів відбувається в тісному взаємозв'язку з розвитком їх профеесійної компетентності.

Ключові слова: медіакультура педагога, медіатворчість, медіаосвіта, післядипломна педагогічна освіта, інформаційно-циоррові технології.
\end{abstract}

In the article the problem of development of media culture of modern teacher by means of media creativity in institution of postgraduate pedagogical education is covered. The relevance of the material is due to changing requirements for the professional activity of teachers in the information society. The essence of the concepts of media culture and media creativity of the teacher are revealed, characterized by the level of formation of skills of creative perception, analysis, interpretation, creation of own media resources and ability to apply these skills in professional activity. Attention is focused on the priority task for each teacher - to learn how to create their own media products, to evaluate the quality of information, to be selective in the process of its consumption, to be critical of sources of information. Various approaches to the development of media culture of teachers in the system of postgraduate education are presented: through the introduction of a special course in media culture, through the integration of media education technologies in the educational process, through the fulfillment of individual creative tasks with the help of media resources. Attention is paid to the rules of communication culture in the information space, ways of protection against negative influences of media in the process of communication.

The methodological conditions for the effective development of the media culture of teachers in the institution of postgraduate pedagogical education are substantiated: formation of positive motivation for the use of media resources by teachers; teachers' knowledge and skills in the use of digital technologies; use of interactive communications in the learning process; engaging teachers in active creative media activities by creating their own educational products. It has been found that the development of media culture and media creativity of teachers occurs in close connection with the development of their professional competence.

Key words: teacher's media culture, media creation, media education, postgraduate pedagogical education, information and digital technologies.
Постановка проблеми в загальному вигляді. В Україні посилюється інтерес до проблеми професійного розвитку педагогів у системі неперервної педагогічної освіти. Одним із пріоритетних напрямів модернізації освіти на сучасному етапі визначено підготовку педагогів до здійснення професійної діяльності з урахуванням інтеграції медіа в усі галузі життя й, зокрема, в освітній процес.

Сучасна стратегія розвитку освіти спрямована на фрормування ключових компетентностей в інтелектуальній, суспільно-політичній, комунікаційній та інформаційній сорерах. Сьогодні вже неможливо уявити навчальний заклад без електронних підручників, комп'ютерних програм для діагностики знань, інтерактивних форм обговорення актуальних навчальних проблем. Усе це ставить високі вимоги до підготовки педагогічних кадрів, зокрема, уміння працювати в інфрормаційно насиченому суспільстві.

Серед перспективних напрямів розвитку системи освіти відзначені тенденції щодо формування умов для забезпечення самореалізації вчителя в умовах інформатизації суспільства та освітнього простору. На сьогодні одним з актуальних завдань, що стоїть перед вчителями, є творче використання мультимедійних засобів та технологій у профресійній діяльності. 
Аналіз останніх досліджень і публікацій. Проблема розвитку медіакультури особистості знайшла відображення в історії зарубіжної (Д. Букінгем, К. Ворсноп, Л. Зазнобіна, Р. К'юбі, Л. Мастерман, Ю. Усов, О. Федоров, Е. Харт, О. Шариков та інших) та вітчизняної (Л. Найдьонова, Г. Онкович, Л. Масол, Л. Бойченко, Н. Габор, Ю. Казаков, І. Міщишин, Б. Потятиник та інших) наукової думки. Творча активність педагога в процесі використання засобів мультимедійних технологій у професійній діяльності розглядалася в працях європейських дослідників С. Френе, Д. Брауна, Б. Брехта, Дж. Шевальє, М. Мартіні.

Виділення не вирішених раніше частин загальної проблеми. Проте у зазначених наукових працях недостатньо розглянута проблема розвитку медіакультури та творчості педагога в медійній сорері, а також практично відсутній аспект їхнього розвитку в системі післядипломної педагогічної освіти.

Мета статті полягає в обґрунтуванні необхідності розвитку медіакультури вчителів в умовах сучасного інфрормаційного суспільства, окресленні практичних аспектів процесу розвитку медіакультури педагогів засобами медіатворчості у закладах післядипломної освіти.

Виклад основного матеріалу. Сучасний інформаційний медіапростір ставить нові вимоги до професійної підготовки педагога, серед яких вагомими $€$ володіння інфрормаційно-цифровими технологіями, методиками презентації навчальної інорормації, здатність забезпечувати творчо-пошуковий характер навчання, уміння використовувати мультимедійні технології, тобто володіння високим рівнем медіакультури. Реалії інфрормаційного суспільства не дозволяють медіакультуру розглядати тільки як набір способів обробки інфрормації за допомогою цифрових засобів. Вона включає в себе компоненти, пов'язані з культурою пізнання, саморозвитку особистості, передачі та фрормування системи знань, транслювання результатів пізнавальної діяльності суспільству.

3 середини $\mathrm{XX}$ століття, 3 усвідомленням потреби в нових знаннях та навичках пріоритетним напрямом модернізації освіти стало теоретичне обґрунтування її медіаосвітнього складника, орієнтованого на розширення можливостей для викладання та навчання на різних рівнях освіти шляхом використання сучасних медіазасобів та інформаційно-цифрових технологій.

У 2010 році в Україні була прийнята Концепція впровадження медіаосвіти, яка серед головних завдань визначала сприяння формуванню здатності до медіатворчості для компетентного й здорового самовираження особистості, реалізації їі життєвих завдань, розвитку згуртованості, солідарності, покращення якості міжособової комунікації й приязності соціального середовища, доброзичливості в мережі стосунків, а також якості життя в значущих для особистості спільнотах [6].

У межах медіаосвіти ставляться акценти на творче сприймання медіа та розвиток здатності особистості до створення власної медіапродукції. Медіаосвіта в Україні орієнтована на використання нових способів комунікації, на активне творче сприймання та створення освітніх медіатекстів. Усе це становить медіакультуру - складне структурне утворення, що передбачає ефективну взаємодію 3 мас-медіа, яка сприяє розвитку знань, умінь, навичок повноцінного сприймання та інтерпретації інфрормації за допомогою медіаресурсів. Іншими словами, медіакультура - це процес, результатом якого є нові медіазасоби, медіатехнології та медіапродукція у фрормі освітніх веб-ресурсів, книжок, періодичних видань, радіо та телепрограм, документальних та художніх фрільмів тощо.

Впливаючи на зміст і характер сучасного освітнього простору, медіатворчість виступає одним із головних чинників розвитку медіакультури педагогів, створення освітніх інновацій із застосуванням інфрормаційно-цифрових технологій. Якщо творчість у широкому розумінні - це створення нового, оригінального продукту, то медіатворчість - створення нового (чи перетворення існуючого) в сорері медіа або за допомогою медіазасобів. Особливо актуальна проблема медіатворчості для України, де глобальні тенденції медіатизації загострюються станом національного медіаландшафту, який знаходиться на стадії становлення, а система медіаосвіти робить свої перші кроки.

Звернувшись до робіт вітчизняних і зарубіжних учених, автор простежив, що поняття «медіа творчість» постійно розширює своє значення. У словнику термінів з медіаосвіти відомий медіапедагог О. Федоров дає таке визначення: «медіатворчість - процес творчої діяльності в медіасфрері та її предметні результати, взаємопов'язані процеси проективної діяльності та виробництва медіа текстів» [9].

В Україні феномен медіатворчості досліджували науковці Л. Найдьонова та Н. Череповська. У дослідженнях Н. Череповської медіатворчість ототожнюється з ресурсами людини, як системою іiї внутрішніх можливостей, засобів, її творчого потенціалу, які вона може застосувати у необхідних момент або у повсякденному житті і які спрямовані на перетворення медіа реальності в умовах становлення інфрормаційного суспільства [11].

Медіатворчість визначається науковцями як френомен зі складною структурою, осмислення якого почалося нещодавно, у результаті розширення освітніх функцій медіа, формування такого напряму як медіаосвіта, застосування дистанційнихорорм навчання, активноговикористанняінформаційно-цифрових технологій в освітній практиці. 
У контексті досліджуваної проблеми медіатворчість педагога автор буде розглядати як особливу фрорму творчого пізнання, створення та поєднання електронних мультимедійних продуктів, що супроводжується креативною діяльністю.

Автор вважає доречним зазначити, що значущість медіатворчості у розвитку медіакультури педагога зумовлена, по-перше, необхідністю володіння новими навичками та компетентностями, пов'язаними із застосуванням інорормаційно-циорових технологій, осмисленням ролі медіа та фрормуванням медіакультури у суб'єктів освіти (учнів, батьків); по-друге, недостатньою вивченістю впливу медіа на освітній простір; по-третє, складністю та багатогранністю явища медіатворчості.

Транслюючи розуміння медіатворчості на систему педагогічної діяльності, слід зауважити, що важливою умовою ії розвитку є включення вчителя в процес педагогічної творчості як вміння вибудовувати індивідуальні освітні стратегії, методичні та дидактичні інновації. Творча педагогічна діяльність засобами нових медіа повинна мати неперервний характер. У зв'язку з цим, процес медіатворчості педагога є невід'ємною частиною навчального процесу післядипломної освіти та виражається в усвідомленому сприйнятті, оцінюванні та створенні медіаосвітніх продуктів. Це безперервний процес креативної діяльності протягом усієї педагогічної діяльності вчителя, який визначає ступінь його профресійного та творчого розвитку, а також рівень медіакультури. Саме тому медіакультура як суспільний френомен створює нове середовище існування, нову реальність, що дає можливість педагогу бути сучасним, активно діяти в інформаційному освітньому середовищі, використовувати найновітніші досягнення науки та техніки.

Ефективним механізмом розвитку медіакультури та медіатворчості вчителів є заклади післядипломної педагогічної освіти, які скеровують свою роботу на вдосконалення професійної майстерності педагогів відповідно до вимог інформаційного суспільства. Тому розвиток медіакультури вчителів у закладах післядипломної педагогічної освіти автор розглядає як спеціально організований медіаосвітній процес, що здійснюється на основі використання доцільно відібраних фрорм, методів, засобів навчання.

Одним із шляхів вирішення актуалізованої проблеми є цілеспрямований розвиток медіакультури педагогів через впровадження спецкурсу «Медіакультура вчителя», який передбачає оновлення медіазнань (уявлень, термінів, фрактів, які відображають систему мас-медіа), вдосконалення медіавмінь (здійснення медіаосвітньої діяльності на основі медіазнань) та медіанавичок (здійснення медіаосвітньої діяльності на рівні автоматизованих дій) педагогів.
Мета пропонованого курсу на стратегічному рівні вимагає здійснення спеціальної підготовки вчителів, яка полягає у вдосконаленні професійних знань, умінь, навичок, спрямованих на забезпечення державного замовлення. Водночас, оперативна мета визначає скерованість реалізації професійної підготовки у закладах післядипломної педагогічної освіти на розвиток медіакультури вчителів. Учителю для розвитку власної медіакультури та медіатворчості необхідні як загальні, так і спеціальні знання, оскільки сорормованість знань тільки окремої групи призводить, як показують висновки науковців та практика, до обмеженості й малопродуктивності певного виду діяльності [5].

Для розвитку медіакультури вчителів у процесі підвищення кваліфікації слід виокремити такі засоби як інфрормаційно-цифрові технології, веб-освітні ресурси, хмарні технології та інші. Медіатворчість педагога найбільш ефективно виявляється в процесі створення мультимедійних проектів, власних освітніх ресурсів, інтерактивних вправ, під час виконання творчих завдань (створення фрлеш презентацій, фотоколажів, відео), що й сприяє розвитку його медіакультури.

Практична спрямованість творчої діяльності вчителя з використанням програмних і технічних комп'ютерних засобів дозволяє фрормувати такі вміння та якості вчителя XXI століття, як відповідальність і адаптивність, комунікативність, креативність і допитливість, критичне й системне мислення, уміння працювати зінформацією та медіазасобами, міжособистісна взаємодія і співпраця, уміння ставити й вирішувати проблеми, спрямованість на саморозвиток, соціальна відповідальність.

Використання активних та інтерактивних форм і методів навчання на курсах підвищення кваліфрікації, в тому числі розробка творчих проектів, участь у стартапах, майстер-класах, фрорсайтах, коворкінгах забезпечує реалізацію принципу творчої активності всіх учасників освітньої взаємодії. Корегування професійної діяльності вчителів проходить із урахуванням якісних показників та критеріїв рівня розвитку медіакультури. Це дозволяє ефективно оцінювати зміст досягнутих результатів, прогнозувати нові досягнення; вдосконалювати механізми, які сприяють успішному виконанню різноманітних фахових завдань, виявляти й перевіряти фрактори, які перешкоджають розвитку медіакультури; здійснювати аналіз професійної діяльності тощо.

Важливим аспектом медіакультури педагога постає його критичне ставлення до інфрормації, дотримання етичних норм при використанні медіаресурсів, а також Кодексу про авторське право, захисту інформації та користувачів загальними інформаційними ресурсами, передбачення наслідків некоректної поведінки в інорормаційному середовищі [1]. 
Медіакультура та медіатворчість є потужним ресурсом особистості педагога, забезпечуючи його адаптацію до сучасних умов існування у світі медіареальності інорормаційного суспільства; розширення комунікаційних можливостей; можливість самореалізації; збагачення професійного досвіду.

Висновки. Розвиток медіакультури педагогів засобами медіатворчості у закладах післядипломної педагогічної освіти здійснюється шляхом вдосконалення професійних знань, умінь, навичок за допомогою медіаресурсів, оволодіння різними способами та прийомами знаходження, опрацювання, передачі та презентації інфрормації. Отримані результати свідчать про необхідність подальшого поглибленого теоретико-практичного вивчення змісту розвитку медіакультури вчителів у процесі підвищення кваліфрікації, професійно-орієнтованої розробки та впровадження фрорм, методів і засобів підготовки педагогів до здійснення медіаосвітньої діяльності в закладах освіти, урахування при організації курсової підготовки педагогічних працівників перспективних напрямів застосування медіаресурсів у професійній діяльності.

\section{БІБЛІОГРАФІЧНИЙ СПИСОК:}

1. Баловсяк Н.В. До проблеми визначення структури профресійної компетентності фрахівця. Профресійна та моральна культура в педагогічній системі : зб. наук. пр. Харків-Луганськ, 2004. С. 6-14.
2. Васянович Г.П. Педагогічна етика : Навч.метод. посіб. Львів, 2005. 343 с.

3. Візуальна медіакультура: культурологічний і соціально-психологічний аспекти: URI: http://ito.vspu. net/ENK/2016-2017/sythasn_medd_osvita_34/navch. mat/Lek/lek_1.pdf (дата звернення: 14.11.2019).

4. Коваль Т.І. Підготовка викладачів вищої школи. Інформаційні технології у педагогічній діяльності : навч.-метод. посіб. Київ, 2009. 380 с.

5. Колеснікова І.В. Розвиток медіакультури вчителів у закладах післядипломної педагогічної освіти : авторефр. ... канд. пед. н. Житомир, 2018. 20 с.

6. Концепція впровадження медіаосвіти в Україні: URI: http://osvita.mediasapiens.ua/mediaprosvita/ mediaosvita/kontseptsiya_vprovadzhennya_ mediaosviti_v_ukraini_nova_redāktsiya (дата звернення:14.11.2019).

7. Концепція Нової української школи: URI: https:// www.kmu.gov.ua/storage/app/media/reforms/ukrainskashkola-compressed.pdf (дата звернення: 14.11.2019).

8. Мантуленко В.В. Образовательные возможности новых медиа. Самара, 2005. 285 с.

9. Федоров А.В. Словарь терминов по медиаобразованию, медиапедагогике, медиаграмотности, медиакомпетентности. Таганрог, 2010. 64 с.

10. Череповська Н.І. Медіатворчість як соціальнопсихологічний ресурс особистості. Типологія відеосприймання / Збірник наукових праць Інституту психології АПН України «Актуальні проблеми психології» у 12 томах / за ред. В.О. Моляко. Т. 12. Вип. 8. Житомир, 2009. С. 318-325. 